\title{
TOOLS OF CUSTOMER FEEDBACK AND FREQUENCY OF USING BY THE ACCOMMODATION FACILITY IN THE CZECH REPUBLIC
}

\author{
[Nástroje zpětné vazby a jejich používanost ubytovacími kapacitami v České \\ republice]
}

\author{
Jitka Novotová ${ }^{1}$ \\ ${ }^{1}$ Technická univerzita v Liberci, Ekonomická fakulta, Voroněžská 13, 46001 Liberec 1 \\ E-mail: jitka.novotoval@tul.cz.
}

\begin{abstract}
This paper deals with problems of the customer feedback collection by accommodation facilities in the regions of Ústí nad Labem, Liberec and Hradec Králové. For these regions is typical a high density of small lodging facilities such as guesthouses and cottages, mostly located in the mountain areas. The aim of the presented research was to determine which tools of online and offline customer feedback are used by the accommodation facilities in these regions and assess the differences in implementation between accommodation types and sizes. Data was collected via electronic questionnaire survey and then statistically evaluated by test of independence. The test data sample consisted of answers collected from 356 respondents. The findings demonstrate that type of accommodation has no significant impact on the implementation of communication tools. On the other hand, we observed statistical difference for facility size over/under 29 beds and also for annual turnover over/under 1 million Czech crowns.
\end{abstract}

Key words: accommodation, customer feedback, email, personal interviews, social sites.

JEL classification: L83, M31

Doručeno redakci: 29.2.2016; Recenzováno: 6.3.2016; 17.3.2016; Schváleno k publikování: 26.5.2016

\section{Úvod}

Spokojenost zákazníka je častým tématem výzkumů v pohostinství (Torres a Kline, 2013). Manažeři ubytovacích kapacit by měli mít přehled o tom, jak se u nich líbí jejich návštěvníkům, zda mají nějaké připomínky a náměty na zlepšení. Na jednu stranu tedy zpětná vazba může pomoci ubytovacím kapacitám zlepšit nabídku služeb. Na stranu druhou se může zpětná vazba šířit veřejně, nejčastěji pomocí sociálních médií. Takto šířené informace se nazývají „slovem z úst“ neboli WOM (Liu, Zhang, 2010). WOM se tedy stává velice důležitým nástrojem k nalezení a udržení zákazníků (Duhan et al., 1997), speciálně pro profesionální servis jakým je odvětví ubytování (Reingen and Kernan, 1986). Výzkum Kandampully a Suhartanto prokázal pomocí regresní analýzy vztah mezi spokojeností zákazníka s ubytovací kapacitou a jeho loajalitou k tomuto zařízení. Byla zde měřena spokojenost s recepcí, jídlem, pokojovou službou a cenou hotelu. Všechny čtyři oblasti se podílejí na celkové loajalitě zákazníka nejvíce ovšem pokojová služba, do které byla zahrnuta celková ochota personálu a čistota a komfort pokoje. Tímto faktorem lze tedy nejvíce budovat konkurenční výhodu a získávat loajální zákazníky (Kandampully a Suhartanto, 2000). Právě loajální zákazníci nejčastěji šiří pozitivní WOM a tím lákají potenciální zákazníky k navštívení dané ubytovací kapacity (Červová, 2013). Velice často je ovšem zákazníky zveřejňována negativní zpětná vazba, která může poškodit image ubytovací kapacity (Torres a Kline, 2013). Byrnes ve svém článku uvedl, že až $62 \%$ spotřebitelů se již někdy podívalo na veřejnou recenzi na internetu před tím, než šli nakupovat. Toto zjištění publikoval autor již $\mathrm{v}$ roce 2007, od té doby lze předpokládat jistý nárůst využívanosti tohoto nástroje (Byrnes, 2007). Karásková a Zedková (2014) uvedly, že až 55 \% respondentů si vybírá dovolenou prostřednictví internetu a tedy může koukat i na veřejné recenze. Zpětná vazba je tedy pro 
ubytovací kapacity nesmírně důležitá a měla by být zjišt'ována, kontrolována a využívána k prezentaci ubytování.

Tento článek poukazuje na důležitost veřejné zpětné vazby pro ubytovací kapacity a ukazuje nedostatky v praktickém využití těchto nástrojů menšími ubytovacími kapacitami ve vybraných lokalitách. Př́nos článku pro laickou veřejnost lze spatřovat v definování nejpoužívanějších nástrojů zpětné vazby, které lze velmi jednoduše implementovat do celkového konceptu ř́zení provozovny a dále poukazuje na pozitivní vliv těchto nástrojů v budování dobrého jména ubytovací kapacity. Pro odbornou veřejnost představuje článek použitelnou metodiku pro další zkoumání a nabízí základní vhled do zkoumané problematiky, na který lze v budoucnu dále stavět.

$\mathrm{Na}$ základě rozhovorů s majiteli a manažery ubytovacích kapacit byly identifikovány nejpoužívanější nástroje zpětné vazby a to osobní dotazování, papírový dotazník, telefonické dotazování, email, sociální sítě a online dotazníky na webových stránkách. Dále článek nabízí ověření několika výzkumných otázek, které identifikují vazby mezi typem a velikostí podniku a využíváním jednotlivých komunikačních nástrojů. Typy podniků byly pro výzkum převzaty od Asociace hotelů a restaurací České republiky, která na základě usnesení vlády ze dne 17. 7. 1999 a za podpory Ministerstva pro místní rozvoj ČR a České centrály cestovního ruchu CzechTourism sestavila „Oficiální jednotnou klasifikaci ubytovacích zařízení České republiky. Ubytovací kapacity jsou rozděleny do kategorií hotel, hotel garni, penzion, motel a botel (Asociace hotelů a restaurací České republiky, et al, 2013).

Článek je rozdělen do několika kapitol, první kapitola seznamuje čtenáře s internetovými nástroji, které vyšly ve výzkumu jako nejpoužívanější, tedy email a sociální sítě a formuluje výzkumné otázky. Druhá kapitola představuje metodologii, která byla ve výzkumu použita a dále strukturu respondentů dotazníkového šetření. V praktické části jsou definovány všechny nástroje zpětné vazby a u nejpoužívanějších nástrojů osobního dotazování, emailu a sociálních sítí jsou testovány výzkumné otázky o vztahu typu nástroje a typu ubytování. Závěr práce shrnuje všechny dosažené výsledky a porovnává je s vytyčenými cíly. V neposlední řadě je zde naznačen možný postup dalšího zkoumání v této problematice.

\section{Nejpoužívanější nástroje zpětné vazby}

V teoretické části budou rozebrány dva nejpoužívanější online nástroje zpětné vazby: e-mail a sociální sítě. E-mail je tradiční internetový nástroj, který se pro zjišt'ování zpětné vazby využívá několik let. Sociální sítě lze zařadit mezi novější nástroje, které se neustále vyvíjejí. V praktické části bude následně rozebrán ještě nejpoužívanější offline nástroj, kterým je osobní dotazování. Pro tento jednoduchý nástroj zpětné vazby byly stanoveny dvě výzkumné otázky (VO) dle předpokladu, že tento nástroj pro svoji jednoduchost mohou využívat i malá ubytovací zařízení (charakteristika zařízení je uvedena v kapitole „Charakteristika respondentü"):

\section{VO1: Osobně zpětnou vazbu zjišt’ují převážně malé ubytovací kapacity s obratem do 1 mil. Ǩ̌ ročně.}

VO2: Osobně zpětnou vazbu zjišt'ují zařízení s menší kapacitou do 29 lůžek.

\subsection{Email}

Direct mailing je již mnoho let velice oblíbenou formou komunikace se zákazníky. Z pohledu marketingu je využíván $\mathrm{k}$ mnoha účelům (Naftová, 1999). Hlavním cílem mailingu je vyvolat dialog se zákazníkem a získat zpětnou vazbu, respektive prŕímou a měřitelnou odezvu. Mezi 
subjektem a cílovou skupinou není přímý kontakt, veškerá komunikace včetně zpětné vazby probíhá prostřednictvím média (Pospíšil a Závodná, 2012). Výzkumy minulých let ukazují vysokou efektivnost tohoto nástroje v komunikaci s potenciálními zákazníky. V dnešní době tato efektivita kvůli velkému přesycení emaily a také kvůli častým spamům výrazně klesá. Spam je jedním z největších problémů mailingu. Spamy jsou nevyžádaná pošta, která není určená přímo pro daného př́jemce zprávy. Odhaduje se, že v roce 2009 bylo více než $97 \%$ emailů ohodnoceno jako spam (Alsmadia a Alhamib, 2015). I přes tyto problémy se email stále úspěšně využívá ke komunikaci s již stávajícími zákazníky (Chittenden a Rettie, 2003).

V cestovním ruchu v České republice hraje email stále nezastupitelnou roli v oblasti přijímání objednávky na ubytování i v následné komunikaci mezi zákazníkem a ubytovací kapacitou. Email k této komunikaci používá až $93 \%$ ubytovacích zařízení. Obliba emailu spočívá v jeho rychlosti a nulových nákladech na komunikaci ze strany zákazníka. Email lze však využít i pro hodnocení uskutečněného pobytu a hodnocení následně použít jako veřejnou recenzi (Semerádová et al., 2014).

Frekvence používanosti emailu ve zpětné vazbě je předmětem výzkumu tohoto článku spolu s určením toho, jaké ubytovací kapacity email nejčastěji implementují. Používání emailu vyžaduje značné úsilí, znalosti a čas na rozesílání emailů a vyhodnocení odpovědí. Proto byly stanoveny dvě výzkumné otázky (VO) založené na úvaze, že větší ubytovací kapacity mají zdroje na to, aby emaily používaly (charakteristiky jednotlivých kategorií ubytování jsou představeny v kapitole „,Charakteristika respondentü “).

\section{VO3: Email ke zpětné vazbě využívají hlavně hotely. VO4: Email využívají převážně větší ubytovací kapacity nad 29 lůžek.}

\subsection{Sociální sítě}

Sociální sítě lze označit za místo, kde se setkávají a interagují lidé v bezprecedentně rychlém čase a utvářejí tak rozsáhlé znalostní prostředí (Lee, 2013; Ye, 2012). Pospíšil a Závodná (2012) podotýkají, že sociální sítě jsou virtuálním místem, na němž se scházejí lidé a dobrovolně sdílejí osobní informace prostřednictvím svých profilů. Janouch (2011) dodává, že sociální média se nepřetržitě mění tím, jak přibývá jejich obsah a také jejich funkce. Marketing se díky sociálním sítím stává precizním, osobním, sociálním a interaktivním nástrojem pro účinné oslovení zákazníků (Shih, 2010). Všichni zde zmiňovaní autoři se shodují, že sociální sítě jsou založeny na sdílení informací mezi uživateli. Sdílení informací tedy představuje podstatu sociálních sítí. Dalším lákadlem pro uživatele je možnost komunikovat se známými a kamarády, s kterými by se $\mathrm{v}$ běžném životě z důvodů vzdálenosti nebo časové tísně běžně nesetkali, ale také s cizími lidmi a vzájemně si vyměňovat svoje zkušenosti a zapojovat se do diskuzí. Ungerman (2015) dělí sociální sítě na klasické sítě (Facebook, MySpace, LinkedIn, Google+), mikro blogy (Twitter) a multimédia (YouTube, Instagram).

Největší klasickou sociální sítí na světě je bezesporu Facebook, který byl založen 1. února 2004 Markem Zuckerbergem, studentem Harvardské univerzity. V roce 2006 byl Facebook otevřen pro širokou veřejnost, kdy se mohli zaregistrovat všichni lidé nad 13 let (Treadaway a Smithová, 2011). Facebook zaznamenává již od svého založení extrémní zájem lidí po celém světě. Každým dnem se registrují tisíce nových uživatelů. Tento trend však začíná pomalu zpomalovat, jak se snižují počty těch, kteří mají prŕístup na internet a stále nejsou uživateli. V březnu roku 2012 byl zaznamenaný počet uživatelů na celém světě 901 milionů. 14. září téhož roku ve 12:45 kalifornského času padlo mystické číslo 1 miliarda (Česká 
televize, 2012). V roce 2014 by počet aktivních uživatelů Facebooku, kteří se připojují alespoň jednou měsíčně, 1,28 miliardy. Jednalo se o $4 \%$ nárůst oproti roku 2013. Jednou denně pak Facebook navštívilo 802 milionů uživatelů (nárůst o 5,7 \%) (Janů - Mladá fronta, 2014). Začátkem roku 2015 stoupl počet aktivních uživatelů již na 1,393 miliardy (Kopřiva, 2015). Českých uživatelů je dle informací ze samotného Facebooku okolo 4,5 milionu (Facebook, 2016).

Druhou největší globální sociální sítí je Twitter. Jedná se o mikroblog, který je dennodenně využíván miliony uživatelů ke komunikaci jejich krátkých zpráv nazývaných tweet. Jde o ohromnou virální sílu, která může ovlivnit velké masy. Mnohé výzkumy zjistily, že hlavním důvodem používání Twittru je možnost sdílení zpráv. Tento fakt přináší pro oblast marketingu veliký potenciál (Rudat a Buder, 2015).

V oblasti cestovního ruchu hrají sociální sítě signifikantní roli např́iklad při hledání informací a rozhodovacím procesu potenciálního turisty, nebo v propagaci turistické lokality či celé země. Dle výzkumu z roku 2013 se V České republice běžně na sociální síti Facebook radí o nákupu zboží a služeb až 23 \% uživatelů, 29 \% pak této možnosti využívá občas (Novotová, 2013). Fotis et al. v roce 2012 publikoval výzkum vlivu sociálních sítí v cestovním ruchu. $\mathrm{Na}$ vzorku 346 respondentů z Ruska a dalších postsovětských republik identifikoval, že nejvíce cestovatelé sociální sítě využívají po př́jezdu z dovolené, kdy zde sdílí své zážitky a fotografie $z$ dovolené. Dále bylo prokázáno, že se lidé nechávají ovlivnit při výběru destinace i samotného ubytování informacemi na sociálních sítích. Sociální sítě jsou brány jako věrohodný zdroj a to dokonce více než oficiální stránky ubytovací kapacity, kde jsou podle názoru většiny respondentů úmyslně zkresleny informace (Fotis, Rossides a Buhalis, 2012). Průzkum provedený v roce 2013 ukázal, že nejdůvěryhodnější sociální sítí pro hledání informací o dovolené je TripAdvisor, který byl v tomto výzkumu zařazen mezi sociální sítě. Na druhém místě se umístil Facebook (Munar a Jacobsen, 2013). Využití sociálních médií na poli cestovního ruchu se tedy ukázalo jako vynikající strategické rozhodnutí (Zeng a Gerritsen, 2014).

Sociální sítě pro získávání zpětné vazby nejsou českými ubytovacími zařízeními ještě zdaleka tak využívány, jako $\mathrm{v}$ oblasti komunikace $\mathrm{s}$ potenciálním zákazníkem. Sociální média k získávání zákazníků využívá asi polovina ubytovacích zařízení, k zjištování zpětné vazby ale jenom pětina z nich (Němečková, et al., 2014). Je patrné, že firmy cestovního ruchu působící na českém trhu ještě zdaleka neumí využít veškerý potenciál sociálních sítí, které jsou velice vhodné ke sdílení recenzí zákazníků.

Na základě těchto informací byly stanoveny výzkumné otázky (VO) o použití sociálních sítí hlavně většími ubytovacími kapacitami, kterými jsou hotely a dále ubytovací kapacity nad 29 lůžek (charakteristiky jednotlivých kategorií ubytování jsou představeny v kapitole „, Charakteristika respondentü").

\section{VO5: Sociální sítě ke zpětné vazbě využívají převážně hotely. VO6: Sociální sítě využívají ubytovací zařízení s kapacitou nad 29 lůžek.}

\section{Metodologie}

Byl proveden kvantitativní výzkum, jehož cílem bylo identifikovat prvky a procesy internetového komunikačního modelu se zákazníky ve fázi zjišt’ování zpětné vazby a to z pohledu ubytovacích kapacit. Cílový soubor zahrnoval všechny ubytovací kapacity v Libereckém, Ústeckém a Královéhradeckém kraji. Dle databáze Českého statistického 
úřadu se celkem v těchto krajích nachází 2835 ubytovacích zařízení různých typů (ČSÚ, 2014). Výzkum byl realizován prostřednictvím online dotazníku v programu Google Disk, jehož odkaz byl distribuován pomocí emailu. S ohledem na problematiku výzkumu bylo dotazování pomocí internetového dotazníku vyhodnoceno jako nejlepší a sloužilo i k prvotnímu roztř́iění respondentů na ty, co používají ke komunikaci alespoň email a těch, kteří ke svému podnikání email nepoužívají.

Prvotní explorační výzkum měl za úkol zjistit, zda má ubytovací zařízení alespoň webové stránky a email, kam by mohl být odeslán dotazník. Výzkumem bylo zjištěno, že 45 \% všech ubytovacích zařízení internet ke komunikaci se zákazníky nevyužívá. Rozsah základního souboru byl tedy stanoven na 1559 zařízení, která mají alespoň nějakou formu komunikace, tj. webové stránky a email. Jelikož se průměrná návratnost dotazníků rozeslaných emailem v literatuře uvádí okolo $20 \%$, byl výběrový soubor stanoven ve stejné výši jako rozsah základního souboru, tedy 1559 (Pecáková, 2011; Kozel 2007; Hindls et al, 2000). Pomocí emailu bylo možno rozeslat takovéto množství zpráv ve velice krátkém čase. Email byl adresován majitelům a manažerům ubytovacích zařízení, kteří jsou zodpovědní za marketingovou komunikaci. Dle původního předpokladu byla celková návratnost př̀i počtu 356 odpovědí $22,83 \%$. Snahou bylo získat odpovědi od respondentů ve stejném poměru, jakému odpovídá skutečné zastoupení podle jednotlivých typů ubytování. Typ ubytovacího zařízení byl zvolen jako trî́dící kritérium na základě úvahy autorky článku, která předpokládala, že právě toto kritérium je významným činitelem variability základního souboru.

\section{Cílem výzkumu bylo zjistit, jaké komunikační nástroje zpětné vazby jsou v současnosti využívány a jaké typy ubytovacích kapacit je využívají nejčastěji.}

Data získaná dotazníkovým šetřením byla vyhodnocena ve statistickém programu Statgraphics a to pomocí testu nezávislosti slovních proměnných. Ve výzkumu byly všechny testy provedeny na hladině významnost $\alpha=0,05$. Síla závislosti byla měřena pomocí Cramérova kontingenčního koeficientu nabývající hodnot $\mathrm{z}$ intervalu $<-1,1>$. Závislost se považuje za tím silnější, čím je hodnota koeficientu bližšś jedné (Hindls et al, 2000).

\subsection{Charakteristika respondentů}

Tabulka č. 1 ukazuje rozložení respondentů v šetření dle typu ubytovacího zařízení. Kategorie ubytovacích kapacit byly rozebrány v úvodu článku. Pod pojem „Jiná nespecifikovaná zařizeni" lze zařadit všechny ubytovací kapacity, které nesplňují podmínky pro zařazení do jednotlivých kategorií. V severních Čechách do této kategorie spadá řada horských chat nacházejících se př̀evážně v Jizerských a Lužických horách.

Tabulka 1: Zastoupení respondentů dle typu ubytovacího zařízení

\begin{tabular}{lll}
\hline typ ubytování & četnost & četnost $\mathrm{v} \%$ \\
\hline hotel & 47 & 13,2 \\
penzion & 138 & 38.8 \\
turistická ubytovna & 43 & 12 \\
chatová osada & 17 & 4,8 \\
kemp & 12 & 3,4 \\
\hline Jiné nespecifikované zařízení & 99 & 27,8 \\
\hline suma & 356 & 100 \\
\hline Zdroj: vlastní zpracování & &
\end{tabular}

Zdroj: vlastní zpracování 
Ubytovací zařízení lze obecně zařadit do kategorie drobného nebo malého podniku, který je dle Evropské unie vymezen výší ročního obratu do 2 milionů Euro, respektive 10 milionů Euro a počtu zaměstnanců do deseti či padesáti. Toto tvrzení bylo potvrzeno výzkumem, kdy jen $2 \%$ respondentů uvedlo svůj obrat vyšší než deset milionů korun a 54 \%stanovilo svůj obrat pouze do jednoho milionu korun. Průměrná kapacita ubytování všech dotázaných ubytovacích zařízení byla 45,075 lůžek a medián 29,5 lůžek. Největší kapacitu mají především hotely následované kempy a chatovými osadami. Přehled obratů a kapacit všech kategorií ubytování obsahuje tabulka č. 2.

Tabulka 2: Velikost jednotlivých typů dotázaných ubytovacích zařízení

\begin{tabular}{|c|c|c|c|}
\hline typ ubytování & průměrná kapacita & medián & roční obrat \\
\hline hotel & 90,85 & 60 & $\begin{array}{l}1-10 \text { mil. Kč.......90\% } \\
\text { Nad } 10 \text { mil. Kč ......10\% }\end{array}$ \\
\hline penzion & 27,9 & 22 & $\begin{array}{l}\text { Do } 1 \text { mil. Kč } \ldots \ldots .72 \% \\
1-3 \text { mil. Kč } \ldots \ldots \ldots .22 \%\end{array}$ \\
\hline turistická ubytovna & 21,4 & 18 & do 1 mil. \\
\hline chatová osada & 80 & 66 & do 1 mil. \\
\hline kemp & 89,3 & 80 & do $1 \mathrm{mil}$. \\
\hline jiné nespecifikované zařízení & 42,8 & 38 & do $1 \mathrm{mil}$. \\
\hline
\end{tabular}

Zdroj: vlastní zpracování

Hotely a penziony představovaly ubytovací zařízení, která dosahují největších obratů. Obrat vyšší než 10 milionů korun ročně uvedlo $10 \%$ dotázaných hotelů. Penziony dosahovaly obraty řádově nižší. Pouze necelá čtvrtina dotázaných penzionů uvedla, že jejich roční obrat se pohyboval v rozmezí $1-3$ miliony korun.

\section{Výsledky výzkumu}

Výzkum se zaměřil na zjištění všech používaných nástrojů zpětné vazby. Nejvyužívanějším klasickým nástrojem byla zjištěna ústní zpětná vazba, kdy se personál ptá na spokojenost zákazníků v průběhu nebo na konci jejich pobytu. Druhým nejpoužívanějším nástrojem je papírový dotazník a třetím telefonické dotazování. Všechny tři nástroje můžeme zařadit do takzvaných offline nástrojů. $Z$ internetových nástrojů se nejvíce využívá email, který je zákazníkům posílán po jejich návratu z ubytování. Na druhém místě skončily sociální sítě, na kterých je možno vyjádřit názor na kvalitu ubytování př́ímo na stránce ubytovací kapacity či formou vlastního př́íspěvku (WOM), dále pak dotazník umístěný na webové stránce ubytovací kapacity. Do kategorie ,jiné" respondenti zařadili hodnocení přes Booking. com nebo slevové portály. Bylo také zjištěno, že 16,5\% respondentů nástroje zpětné vazby nevyužívá vůbec. Frekvence užívání nástrojů je znázorněna na obrázku číslo 1. 
Obrázek 1: Frekvence užívání nástrojů zpětné vazby



Zdroj: vlastní zpracování

\subsection{Zjišt'ování zpětné vazby osobním dotazováním}

Jak již bylo ukázáno na obrázku 1, osobní dotazování je nejvyužívanější nástroj získávání zpětné vazby. Osobní dotazování je technicky i finančně mimořádně nenáročné, proto byly stanoveny výzkumné otázky o využívání této metody častěji zařízeními s nízkým př́imem do 1 milionu Kč (tedy všechny kapacity kromě hotelů, které mají obraty zpravidla větší) a menším počtem lůžek do 29.

V01: Osobně zpětnou vazbu zjišt'ují převážně malé ubytovací kapacity s obratem do 1 mil. Kč ročně.

VO2: Osobně zpětnou vazbu zjišt'ují zařízení s menší kapacitou do 29 lůžek.

Tabulka 3: Testování výzkumních otázek VO1 a VO2

\begin{tabular}{|c|c|c|c|c|c|c|}
\hline Výzkumné otázky & Test & $\begin{array}{c}\text { Hladina } \\
\text { spolehlivosti }\end{array}$ & Statistic & Df & P-Value & Cramer's \\
\hline $\begin{array}{l}\text { Využivání osobní zpětné } \\
\text { vazby a obrat do/nad } 1 \text { mil. Kč } \\
\text { jsou nezávislé }\end{array}$ & $\begin{array}{l}\text { Test } \\
\text { nezávislosti }\end{array}$ & $95 \%$ & 6,997 & 1 & 0,0082 & 0,2972 \\
\hline $\begin{array}{l}\text { Využívání osobní zpětné } \\
\text { vazby a počet lůžek jsou } \\
\text { nezávislé. }\end{array}$ & $\begin{array}{l}\text { Test } \\
\text { nezávislosti }\end{array}$ & $95 \%$ & 4,111 & 1 & 0,0426 & 0,1471 \\
\hline
\end{tabular}

Zdroj: vlastní zpracování

Testováním VO1 můžeme říct, že využívání osobní zpětné vazby je závislé na obratu do a nad 1 mil. Kč. Síla závislosti je středně vysoká. Bylo ale zjištěno, že osobní zpětnou vazbu využívá $90 \%$ zařízení $\mathrm{s}$ větším obratem než 1 milion korun ročně. Malá zařízení zjišt'ují zpětnou vazbu osobně v $73 \%$ případů. Musíme zamítnout tvrzení, že by osobní zpětnou vazbu využívaly více zařízení s nižším obratem, ale naopak bylo prokázáno, že ji využívají častěji ty s vyššími obraty. U výzkumné otázky VO2 bylo prokázáno, že využívání osobní zpětné vazby je závislé na velikosti ubytovacího zařízení podle počtu lůžek. Síla závislosti je ale velice slabá. Opět musíme zamítnout prvotní tvrzení o využívání osobní zpětné vazby převážně menšími kapacitami. Ty používají tento nástroj v $48 \%$, kdežto velké kapacity nad 29 ji používají v 87 \%. Navzdory předpokladu se osobní zpětná vazba více využívá většími ubytovacími zařízeními jak podle obratu, tak podle počtu lůžek. 


\subsection{Email}

Jak již bylo zmíněno $\mathrm{v}$ teoretické části, používání emailu ke zpětné vazbě vyžaduje každodenní kontrolu a aktivní komunikaci ze strany podniku. Proto byly vytvořeny výzkumné otázky o používanosti emailu převážně hotely, které mají povětšinou více zaměstnanců a vyšší obrat, a dále o používanosti většími kapacitami s více než 29 lůžky.

VO3: Email ke zpětné vazbě využívají hlavně hotely.

VO4: Email využívají převážně větší ubytovací kapacity nad 29 lůžek.

Tabulka 4: Testování hypotéz výzkumných otázek VO3 a VO4

\begin{tabular}{llccccc}
\hline Výzkumné otázky & Test & $\begin{array}{c}\text { Hladina } \\
\text { spolehlivosti }\end{array}$ & Statistic & Df & P-Value & Cramer's \\
\hline $\begin{array}{l}\text { email a využívání u hotelů } \\
\text { jsou nezávislé }\end{array}$ & $\begin{array}{l}\text { Test } \\
\text { nezávislosti }\end{array}$ & $95 \%$ & 5,374 & 1 & 0,0204 & 0,1631 \\
$\begin{array}{l}\text { email a velikost podle počtu } \\
\text { lůžek jsou nezávislé }\end{array}$ & $\begin{array}{l}\text { Test } \\
\text { nezávislosti }\end{array}$ & $95 \%$ & 6,843 & 1 & 0,0089 & 0,2869 \\
& & & & & &
\end{tabular}

Zdroj: vlastní zpracování

Na základě testování výzkumné otázky VO3 bylo zjištěno, že využívání emailu ke zpětné vazbě je závislé na typu ubytování. Síla závislosti je ale slabá. $56 \%$ hotelů používá email, ostatní formy ubytování používají tento nástroj pouze v $37 \%$. U výzkumné otázky VO4 bylo prokázáno, že využívání emailu ke zpětné vazbě je závislé na velikosti ubytování. Závislost je středně vysoká. Email používá 50 \% kapacit nad 29 lůžek a pouze 31,6 \% ubytování pod 29 lůžek.

\subsection{Sociální média}

Sociální sítě jsou zatím méně využívaným online médiem pro zpětnou vazbu. Hotely mají dle výzkumu větší ubytovací kapacitu a ve většině případů i vyšší obrat. Proto se dá očekávat, že právě hotely budou průkopníky na poli sociálních sítí a dále pak větší ubytovací kapacity nad 29 lůžek.

VO5: Sociální sítě ke zpětné vazbě využívají převážně hotely.

VO6: Sociální sítě využívají ubytovací zařízení s kapacitou nad 29 lůžek.

Tabulka 5: Testování výzkumných otázek VO5 a VO6

\begin{tabular}{llccccc}
\hline Výzkumné otázky & Test & $\begin{array}{c}\text { Hladina } \\
\text { spolehlivosti }\end{array}$ & Statistic & Df & P-Value & Cramer's \\
\hline $\begin{array}{l}\text { Sociální sítě a využívanost } \\
\text { hotely jsou nezávislé }\end{array}$ & $\begin{array}{l}\text { Test } \\
\text { nezávislosti }\end{array}$ & $95 \%$ & 9,468 & 5 & 0,0918 & \\
$\begin{array}{l}\text { Sociální sítě a velikost podle } \\
\text { počtu lůžek jsou nezávislé }\end{array}$ & $\begin{array}{l}\text { Test } \\
\text { nezávislosti }\end{array}$ & $95 \%$ & 5,939 & 1 & 0,0148 & 0,3741 \\
\hline
\end{tabular}

Zdroj: vlastní zpracování

U výzkumné otázky VO5 se nepodařilo prokázat, že by nejvíce sociální sítě využívali hotely a tedy nemůžeme konstatovat, že využívání sociálních sítí je závislé na typu ubytování. U výzkumné otázky VO6 existuje statisticky významný rozdíl mezi používáním sociálních sítí většími ubytovacími zařízeními a menšími kapacitami. Větší ubytovací kapacity používají 
sociální sítě ve $40 \%$, menší pouze v 17 \%. Můžeme tedy potvrdit, že sociální sítě používají více větší ubytovací zařízení.

\section{Závěr}

Cílem tohoto článku bylo zjistit, jaké nástroje zpětné vazby jsou v současnosti ubytovacími kapacitami využívány. Bylo zjištěno, že se stále nejvíce používá osobní zpětná vazba, která slouží převážně ke zlepšení služeb ubytovacích zařízení. Použití těchto informací k získání nových zákazníků je problematické. Vyžadovalo by to sepsání ústního hodnocení a jeho přepsání např́klad na webové stránky ubytovacích kapacit. Jako nejpoužívanější online nástroj byl identifikován email, který je zaslán po ukončení pobytu. Výhodou tohoto nástroje je online forma, kterou lze snadněji uveřejnit na internetu. Nevýhodou ale zůstává, že se výroky zákazníků rovnou nezveřejňují. Sociální sítě, které poskytují nejjednodušší šíření WOM mezi potenciální zákazníky, v současné době využívá necelých $11 \%$ respondentů. Na základě literární rešerše se dá tento výsledek interpretovat jako velice špatný. Řada zdrojů potvrzuje, že sociální sítě mají v současné době velký vliv při výběru ubytovací kapacity a jsou dokonce vnímány jako důvěryhodnější než webové stránky ubytování. I z tohoto důvodu by měl být minimálně profil na Facebooku samozřejmostí.

Dalším cílem bylo analyzovat, jak jsou nejpoužívanější nástroje zpětné vazby využívány z pohledu typu a velikosti ubytovací kapacity. Za pomoci testu nezávislosti nominálních proměnných bylo zjištěno, že používané nástroje závisí jak na typu ubytování dle oficiální klasifikace, tak na velikosti ubytování. U osobní zpětné vazby byla prokázána závislost na velikosti obratu nad 1 mil. Kč, který mají převážně hotely. Stejně tak email je využíván nejvíce hotely. U sociálních sítí se vliv typu ubytování nepodařilo prokázat. Důvodem může být poměrně malý vzorek respondentů, který tento typ komunikace použivá. Na druhou stranu všechny tři nejvyužívanější nástroje používají více kapacity s více jak 29 lůžky a to dokonce i osobní dotazování. Bylo tedy zjištěno, že nezáleží na finanční náročnosti daného nástroje. Osobní zjištování se jeví jako nejlevnější varianta, která nevyžaduje žádné nástroje nebo dlouhodobou př́ípravu a i přesto ji využívají převážně větší kapacity $s$ vyšším obratem a větším počtem lůžek. Je tedy zřejmé, že malá ubytovací zařízení nevěnují zjišt’ování zpětné vazby takovou pozornost. Důvodem může být větší naplněnost ubytovacího zařízení například z důvodu stále se vracejících věrných zákazníků nebo prostě fakt, že neznají tyto marketingové metody či jim nepřikládají patřičnou důležitost.

V dotazníkovém šetření bylo dále zjištěno, že 16,5 \% ubytovacích kapacit, používajících ke své komunikaci internet, nepoužívá žádný nástroj zpětné vazby. K tomuto číslu je nutno přičíst $45 \%$ kapacit, které internet nepoužívají k žádné formě komunikace se zákazníky, a dostáváme poněkud alarmujících $61,5 \%$ ubytovacích zařízení bez internetové zpětné vazby. Ve třech zkoumaných krajích České republiky tedy internet, potažmo internetovou zpětnou vazbu, využívá pouze $39 \%$ ubytovacích kapacit. Toto číslo je vzhledem k důležitosti internetové komunikace poměrně nízké. Z výsledků literární rešerše vyplývá, že veřejná zpětná vazba je v dnešní době nesmírně důležitá. Velice rychle se rozvíjí komunikace na sociálních sítích a možnost šíření WOM, které může podnikům velice pomoci, ale i uškodit. $\mathrm{V}$ př́padě negativních názorů může být pověst ubytovací kapacity nevratně poškozena. Je tedy potřeba zdůraznit, že nekvalita služeb a následná nespokojenost zákazníků může mít v dnešní době na ubytování mnohem větší vliv, než tomu bylo v minulosti. Manažerům ubytovacích kapacit lze doporučit, aby se nejprve snažili o kvalitní služby a až následně dali zákazníkům prostor $\mathrm{k}$ veřejným recenzím. Cílem by měl být spokojený zákazník, který se časem stává loajálním a šírí o ubytovací kapacitě pozitivní informace, které mohou přilákat řadu dalších zákazníků. 
Závěrem lze říci, že cíle vytyčené v úvodu článku, byly splněny. Jako překvapivé lze hodnotit obecně nízkou používanost internetu ke komunikaci se zákazníky. Na druhou stranu se podařilo prokázat, že větší ubytovací kapacity a hotely zpětnou vazbu využívají a začínají se orientovat i v oblasti novějších médií jakými jsou např́klad sociální sítě. Největším omezením výzkumu je bezesporu poměrně malá návratnost elektronického dotazníku. Výzkum se nezaměřil na příčiny malé návratnosti, a tedy možného zkreslení výsledků. Pro další výzkumy v této oblasti lze doporučit spolupráci s Asociací hotelů a restaurací České republiky či případně s CzechTourismem, kteří by mohly poskytnout dalšímu výzkumu záštitu a tím př́padně zvýšit ochotu manažerů a majitelů ubytovacích kapacit spolupracovat na výzkumu. V rámci dalších výzkumů je možno se zaměřit na prozkoumání situace v celé České republice. Výsledky pro celou ČR lze očekávat rozdílné a to díky zastoupení známých turistických lokalit jakou jsou Praha, Český Krumlov či Karlovy Vary, které lákají i zahraniční klientelu a internet ke své prezentaci jistě využívají.

\section{Poděkování}

Tento článek vznikl za podpory studentské grantové soutěže SGS 21020: „Model internetové komunikace se zákazníkem v odvětví hotelnických služeb“.

\section{Literatura}

[1] Asociace hotelů a restaurací České republiky, Ministerstvo pro místní rozvoj, Evropská unie, CzechTourism, 2013. Oficiální jednotná klasifikace ubytovacích zařizení České republiky 2013-2015 [online]. [vid. 2014-07-03]. Dostupný z: www.hotelstars.cz/resources/files/Metodika\%202013-2015.pdf

[2] BYRNES, N., 2007. More clicks at the bricks. BusinessWeek, 4063, 50-52. ISSN 00077135.

[3] ČERVOVÁ, L, 2013. Hodnota zákazníka v podnikatelských subjektech cestovního ruchu. Liberec: Technická univerzita v Liberci. ISBN 978-80-7494-013-2.

[4] Česká televize, 2012. Počet aktivních uživatelů překonal miliardu. Česká televize [online]. [vid. 2013-01-24] Dostupné z: www.ceskatelevize.cz/ct24/media-it/198374pocet-aktivnich-uzivatelu-facebooku-prekonal-miliardu/

[5] ČSÚ, 2014. Hromadná ubytovací zařízení České republiky. ČSÚ [online]. [vid. 2015-0131]. Praha. Dostupné z: apl.czso.cz/huz/

[6] DUHAN, D. F. et al., 1997. Influence on consumer use of word-of-mouth recommendation sources. Journal of the Academy of Marketing Science, 25(4). ISSN 1552-7824.

[7] FACEBOOK, 2016. Statistika uživatelů Facebooku. Facebook [online]. [vid. 2016-0105]. Dostupné $\quad \mathrm{z}$ : $\quad$ www.facebook.com/ads/audience_insights/people?act= 189052971 \&age $=18-\&$ country $=\mathrm{CZ}$

[8] FOTIS, J., N. ROSSIDES and D. BUHALIS, 2012. Social media use and impact during the holiday travel planning process. In: 19th international conference on information and communication technologies in travel and tourism. Helsingborg, s. 14-24. Dostupné z: johnfotis.blogspot.cz/p/publications.html

[9] HINDLS, R., S. HRONOVÁ a I. NOVÁK, 2000. Metody statistické analýzy pro ekonomy. Praha: Management Press. ISBN 80-7261-013-9. 
[10] CHITTENDEN, L. a R. RETTIE, 2003. An evaluation of e-mail marketing and factors affecting response. Journal of Targeting, Measurement and Analysis for Marketing, 11(3), 203-217. ISSN 0967-3237.

[11] JANOUCH, V., 2011. Internetový marketing. 1. vyd. Brno: Computer Press. ISBN 97880-251-2795-7.

[12] JANŮ, S., 2014. Facebook zveřejnil letošní prŕíjmy, miliarda uživatelů je mobilních. Mladá fronta [online]. [vid. 2014-04-28]. Dostupné z: www.zive.cz/bleskovky/facebookzverejnil-letosni-prijmy-miliarda-uzivatelu-je-mobilnich/sc-4-a-173420/default.aspx

[13] KANDAMPULlY, J. a D. SUHARTANTO, 2000. Customer loyalty in the hotel industry: the role of customer satisfaction and image. International Journal of Contemporary Hospitality Management, 12(6), 346-351. ISSN 0959-6119.

[14] KARÁSKOVÁ, T. a A. ZEDKOVÁ, 2014. Research of cultural tourism and regional gastronomy in the tourist region of Northern Moravia and Silesia. Acta Academica Karviniensia, 14(4), 52-65. ISSN 1212-415.

[15] KOPŘIVA, M., 2015. Nadvláda Facebooku trvá. Vede v počtu nových uživatelů i v ziscích. Hospodářské noviny [online]. [vid. 2016-01-06]. Dostupné z: archiv.ihned.cz/c163509910-nadvlada-facebooku-trva-vede-v-poctu-novych-uzivatelu-i-v-ziscich

[16] KOZEL, R., L. MYNÁŘOVÁ a H. SVOBODOVÁ, 2011. Moderní metody a techniky marketingového výzkumu. Praha: Grada Publishing. ISBN 978-80-247-3527-6.

[17] LEE, D. Y., 2013. The role of attachment style in building social capital from a social networking site: The interplay of anxiety and avoidance. Computers in Human Behavior, 29, 1499-1509. ISSN 0747-5632.

[18] LIU, R. a W. ZHANG, 2010. Informational influence of online customer feedback: An empirical study. Journal of Database Marketing, 17(2), 120-131. ISSN 1741-2439.

[19] MUNAR, A. M. a J. K. S. JACOBSEN, 2013. Trust and involvement in tourism social media and web-based travel information sources. Scandinavian Journal of Hospitality and Tourism, 13(1), 1-19. ISSN 1502-2269.

[20] NAFTOVÁ, J., 1999. Marketingová komunikace není pouze reklama. 1. vyd. Praha: VOX. ISBN 80-86324-00-1.

[21] NĚMEČKOVÁ. J., J. NOVOTOVÁ a T. SEMERÁDOVÁ, 2014. The Level of Implementation and the Effectiveness of Use of Internet Communication Tools in the Marketing Area by Accommodation Facilities in the North Bohemia Region. In: Advances in Informatics, Information Management and Administration. 1. vyd. Liberec: Technická univerzita v Liberci, s. 276-297. ISBN 978-80-7494-144-3.

[22] NOVOTOVÁ, J., 2013. Marketingová komunikace prostřednictvím Facebooku a její praktické použití pro firmu Sleva Liberec. Liberec. Diplomová práce. Technická univerzita v Liberci, Ekonomická fakulta.

[23] PECÁKOVÁ, I., 2011. Statistika v terénnich průzkumech. 2. vyd. Praha: Professional Publishing. ISBN 978-80-7431-039-3.

[24] POSPÍŠIL, J. a L. ZÁVODNÁ, 2012. Jak na reklamu. 1. vyd. Kralice na Hané: Computer Media. ISBN 978-80-7402-115-2.

[25] REINGEN, P. H. a J. B. KERNAN, 1986. Networks in marketing: methods and illustration. Journal of Marketing Research, 13, 370-8. ISSN 0022-2437. 
[26] RUDAT, A. a J. BUDER, 2015. Making retweeting social: The influence of content and context information on sharing news in Twitter. Computers in Human Behavior, 46, 7584. ISSN 0747-5632.

[27] SEMERÁDOVÁ, T., J. NOVOTOVÁ a J. NĚMEČKOVÁ, 2014. The use of online tools during the communication process with customer in the lodging industry: The case of Czech facilities in the North Bohemian region. In: Proceedings of the LCBR European Marketing Conference 2014. 1. vyd. Munich, Germany: Lupcon Center for Business Research, s. 22-30. ISSN 2190-7935.

[28] SHIH, C., 2010. Vydělávejte na facebooku. 1. vyd. Brno: Computer Press. ISBN 978-80251-2833-6.

[29] TORRES, E. N. a S. KLINE, 2013. From customer satisfaction to customer delight. International Journal of Contemporary Hospitality Management, 25(5), 642-659. ISSN 0959-6119.

[30] TREADAWAY, CH. a M. SMITHOVÁ, 2011. Marketing na Facebooku. 1. vyd. Brno: Computer Press. ISBN 978-80-251-3337-8.

[31] UNGERMAN, O., 2015. Social media as a marketing communication tool used by family firms. Acta academica karviniensia, 15(2), 148-162. ISSN 1212-415.

[32] YE, Q. et al., 2012. Can social capital be transferred cross the boundary of the real and virtual worlds? An empirical investigation of Twitter. Journal of Electronic Commerce Research, 13, 20-29. ISSN 1526-6133.

[33] ZENG, B. a R. GERRITSEN, 2014. What do we know about social media in tourism? Tourism Management Perspectives, 10, 27-36. ISSN 2211-9736. 